\title{
Pelaksanaan Pembinaan Narapidana Anak yang Dijatuhi Pidana Penjara Jangka Pendek di Lembaga Pembinaan Khusus Anak (LPKA)
}

\author{
Tiwi Sasmita, Kabib Nawawi, Yulia Monita
}

Fakultas Hukum Universitas Jambi

Author's Email Correspondence: Tiwisasmita123@gmail.com

\begin{abstract}
ABSTRAK
Tujuan artikel ini adalah untuk mengetahui bagaimana pelaksanaan pembinaan narapidana anak jangka pendek di Lembaga Pembinaan Khusus Anak Muara Bulian serta kendala dalam pelaksanaan pembinaan tersebut. Hasil penelitian menunjukkan bahwa Lembaga Pembinaan Khusus Anak Muara Bulian sudah berusaha melakukan pembinaan terhadap narapidana anak sesuai dengan peraturan yang berlaku, pembinaan kerohanian/keagamaan dilakukan melalui kegiatan ceramah dan konsultasi religii yang dilaksanakan secara rutin setiap bulan. Pembinaan fisik dilakukan melalui kegiatan senam pagi dan olahraga lain. Untuk pembinaan terhadap peningkatan dilakukan melalui pelatihan keterampilan pembuatan berbagai kerajinan seperti pembuatan vas bunga dari barang bekas. Kendala dalam pembinaan narapidana anak di Lembaga Pembinaan Khusus Muara BUlian diantaranya, kurangnya perhatian dari keluarga narapidana, kurangnya petugas dan tenaga ahli, kurangnya dana, dan kurangnya partisipasi masyarakat. Oleh karena itu perlu ditingkatkan saran dan prasarana di lembaga pembinaan supaya pembinaan yang didapat oleh anak berjalan maksimal sesuai dengan bakat masing-masing khususnya di bidang pendidikan dan kesehatan.
\end{abstract}

\section{ARTICLE HISTORY}

Submission: 2021-04-23

Accepted: 2021-04-25

Publish: 2021-04-26

KEYWORDS: Guidance, child prisoners; the child penitentiary.
Kata Kunci: Pembinaan, narapidana anak; lembaga pembinaan khusus anak (LPKA).

\begin{abstract}
This article aims to find out how the implementation of short-term guidance of child prisoners at The Children Penitentiary of Muara Bulian and the obstacles in the implementation of the guidance. The result showed that The Children Penitentiary of Muara Bulian has tried to provide the guidance to child prisoners in accordance with applicable regulations, by providing spiritual guidance by helding a monthly religious lectures by clergy presenters at Muara Bulian. In addition, physical development is also given to child prisoners in the form of routine sports such as morning exercise as well as skills development for child prisoners such as making handicrafts in the form of flower vases made from used paper and plastic. The obstacles in guiding child prisoners at The Children Penitentiary of Muara Bulian include the lack of attention from the inmate's family, lack of officers and experts, lack of funds, and lack of community participation. Therefore, it is necessary to improve the facilities and infrastructure so that the guidance received by the children runs optimally according to their respective talents, especially in the fields of education and health.
\end{abstract}

\section{A. PENDAhuluan}

Anak adalah generasi penerus bangsa, masa depan bangsa ditentukan bagaimana kualitas anak saat ini, untuk menjaga harkat dan martabatnya, anak berhak mendapatkan perlindungan khusus, terutama perlindungan hukum. Secara 
konseptual anak yang berhadapan dengan hukum (children in conflict with the law) menurut dalam UU No.11/2012 tentang SPP Anak dalam Pasal 1 angka 2 mengatur tentang pengertian anak yang berkonflik dengan hukum adalah "anak yang berkonflik dengan hukum, anak yang menjadi korban tindak pidana, dan anak yang menjadi saksi tindak pidana. Sementara anak yang berkonflik dengan hukum menurut Pasal 1 angka 3 adalah anak yang telah berumur 12 (dua belas) tahun tetapi belum berumur 18 (delapan belas) tahun yang diduga melakukan tindak pidana".

Berbagai faktor mempengaruhi sehingga terjadinya perbuatan kriminal yang dilakukan anak. Faktor-faktor tersebut tidak hanya faktor yang berasal dalam diri si anak tetapi lebih banyak dipengaruhi oleh faktor eksternal yang lebih banyak disebabkan oleh pengaruh negatif dari kemajuan teknologi dan derasnya arus globalisasi. Selain itu faktor kehidupan orang tua anak juga mempengaruhi perilaku anak. Anak yang kurang mendapatkan perhatian yang layak dari kedua orang tua, lebih banyak berinteraksi dengan teknologi sehingga mengakibatkan perkembangan pribadi yang tidak seimbang dalam diri anak yang pada ahirnya mempengaruhi pola perilaku anak.

Dalam menanggapi permasalahan tersebut, salah satu kebijakan yang ditempuh pemerintah dalam penanggulangan kenakalan anak adalah melalui kebijakan hukum pidana (penal policy), yaitu menerapkan sanksi kepada anak yang terbukti secara bersalah melakukan tindak pidana. Salah satu sanksi yang banyak dijatuhkan oleh pengadilan terhadap narapidana anak adalah sanksi pidana perampasan kemerdekaan dalam waktu yang singkat atau jangka pendek. Walaupun penerapan sanksi pidana melalui proses peradilan pidana merupakan artikel terahir. Proses peradilan anak diutamakan diversi, sebagaimana tujuan diversi "Looking at the purpose of diversion, the juvenile justice process through diversion according to this law still prioritizes the interests of the child who committed the crime, the interests of the victim have not been truly protected" 1

Konsep pidana penjara jangka pendek yaitu pidana penjara yang singkat seperti satu sampai enam bulan, seperti yang dikemukakan oleh Wolf Middendorf, yakni penggunaan pidana penjara jangka pendek seharusnya dikenakan untuk white collar crime dimana pidana denda tidak mempunyai pengaruh. Narapidana bagi pidana penjara jangka pendek harus dipisah dari narapidana penjara jangka panjang ${ }^{2}$.

Terjadinya pidana penjara jangka pendek atau dalam waktu yang singkat kepada narapidana anak adalah karena pidana penjara yang dapat dijatuhkan kepada Anak paling lama 1/2 (satu perdua) dari maksimum ancaman pidana penjara bagi orang dewasa sesuai dengan Pasal 79 Ayat (2) Undang-Undang Nomor 11 Tahun 2012 Tentang Sistem Peradilan Pidana Anak, dengan tuntutan yang lebih rendah dari orang dewasa oleh karena itu jarang sekali narapidana anak mendapat pidana penjara dalam waktu yang lama atau jangka panjang.

1 Hafrida, Restorative Justice in Juvenile Justice to Formulate Integrated Child Criminal Court", Jurnal Hukum dan Peradilan, Vol. 8 No. 3, hlm. 445 diakses dari http://jurnalhukumdanperadilan.org/index.php/jurnalhukumperadilan/article/view/277/220

2 Barda Nawawi Arief, Kapita Selekta Hukum Pidana, Bandung: Citra Aditya Bakti (2003), hlm. 36. 
Mengingat pentinganya pendidikan bagi anak yang berkonflik dengan hukum, dalam Pasal 3 huruf n Undang-Undang Nomor 11 Tahun 2012. Pentingnya pendidikan terhadap anak ini merupakan jaminan negara, pendidikan bagi anak merupakan modal dasar bagi pengembangan kepribadian anak. Hak anak untuk mendapatkan pendidikan sekalipun anak tersebut berada dalam suatu situasi yang sulit yaitu sebagai narapidana anak. Berdasarkan hal tersebut maka pembinaan narapidana anak tetap perlu mengedepankan pendidikan bagi anak. Kehilangan kemerdekaan bagi anak karena berada dalam Lembaga Pemasyarakatan tidak boleh mengakibatkan hilangnya hak anak untuk mendapatkan pendidikan.

Akan tetapi, timbul permasalahan terhadap narapidana anak yang dijatuhi dengan pidana penjara jangka pendek, bagi anak yang sebelum dipidana memang sudah putus sekolah, akan sulit melanjutkan pembinaan khususnya dalam segi pendidikan, tidak bisa memberikan pendidikan paket $\mathrm{b}$ atau c bagi anak untuk mengejar ketertinggalan pendidikan sekolah wajib 9 tahun, itu pula yang mejadi kendala bagi Lembaga Pembinaan Khusus Anak dalam melakukan pembinaan bagi narapidana anak yang dijatuhi pidana penjara jangka pendek.

Untuk mengatasi itu Pemerintah Provinsi Jambi telah menyediakan sarana atau tempat di mana anak yang melakukan tindak pidana dibina, diberi pendidikan, pengajaran di Lembaga Pembinaan Khusus Anak LPKA di Muara Bulian Kabupaten Batang Hari walaupun belum bisa maksimal seperti yang diharapkan dikarenakan adanya beberapa faktor yang menjadi kendala. Tercatat pada Desember 2019, anak binaan di LPKA Muara Bulian berjumlah 34 orang, yang seluruhnya berjenis kelamin laki-laki.

Di dalam pembinaan anak di LPKA, anak pidana tidak boleh dipekerjakan, akan tetapi anak pidana dapat melakukan latihan kerja, pembinaan yang didapatkan oleh anak sesuai dengan ketentuan yang disebutkan di dalam Peraturan Pemerintah Republik Indonesia Nomor 32 Tahun 1999 Tentang Syarat dan Tata Cara Pelaksanaan Hak Warga Binaan Pemasyarakatan, juga mengatur tentang hak dan kewajiban Narapidana dan Anak Didik Pemasyarakatan yang meliputi: "Melakukan ibadah sesuai dengan agama atau kepercayaan; Mendapat perawatan, baik perawatan rohani maupun jasmani; Mendapatkan pendidikan dan pengajaran; Mendapatkan pelayanan kesehatan dan makanan yang layak; Menyampaikan keluhan; Mendapatkan bahan bacaan dan mengikuti siaran media massa lainnya yang tidak dilarang; Mendapatkan upah atau premi atas pekerjaan yang dilakukan; Menerima kunjungan keluarga, penasihat hukum, atau orang tertentu lainnya; Mendapatkan pengurangan masa pidana (remisi); Mendapatkan kesempatan berasimilasi termasuk cuti mengunjungi keluarga; Mendapatkan pembebasan bersyarat; Mendapatkan cuti menjelang bebas; dan Mendapatkan hak-hak lain sesuai dengan peraturan perundang-undangan yang berlaku".

Berdasarkan Pasal 17 Ayat (2) Peraturan Pemerintah Nomor 31 Tahun 1999 Tentang Pembinaan dan Pembimbingan Warga Binaan Masyarakat, pelaksanaan pembinaan narapidana anak yang ada di LPKA Muara Bulian dilaksanakan melalui 3 tahap, yaitu: a. tahap awal; b. tahap lanjutan; dan c. tahap akhir. Artikel ini akan membahas tentang proses pembinaan yang dilakukan, dari tahap awal, lanjutan maupun akhir secara lengkap sesuai data yang di peroleh ketika penelitian di LPKA tersebut. Dengan menganalisa beberapa data lapangan, penulis bisa 
menyimpulkan berbagai persoalan pembinaan di LPKA tersebut dari beberapa sudut pandang yang menguatkan analisa penulis.

\section{B. METODE PENELITIAN}

Penelitian ini merupakan suatu penelitian yuridis empiris. Penelitian yuridis empiris merupakan suatu penelitian melalui pendekatan fakta-fakta yang ada dilapangan dan kemudian dianalisis melalui pendekatan konsep dan teori. Menggambarkan dan menguraikan keadaan atau fakta-fakta yang ada mengenai pelaksanaan pembinaan terhadap narapidana anak di Muara Bulian ditinjau dari Undang-Undang Nomor 12 Tahun 1995 Tentang Pemasyarakatan.

\section{PEMBAHASAN}

\section{Pola Pembinaan Narapidana Anak Yang Dijatuhi Pidana Penjara Jangka Pendek Di Lembaga Pemasyarakatan Anak Muara Bulian}

Beberapa tahapan yang harus di tempuh para Narapidana anak yang menjalani pembinaan di Lembaga Pembinaan Khusus Anak (LPKA) Muara Bulian pada dasarnya adalah anak-anak yang kehilangan kebebasannya untuk bergerak, dalam artian narapidana anak tersebut hanya dapat bergerak di dalam LPKA saja .Masalah pembinaan ini, fokus utamanya adalah narapidana anak, bahkan tidak akan sama pembinaan yang di terapkan untuk narapidana dewasa, banyak hal-hal atau factor yang harus di pertimbangakan dan disesuaikan, salah satu yang sangat harus di pertimbangkan adalah kepentingan terbaik bagi anak itu sendiri. Bagaimana proses pembinaannya, waktunya dan manfaatnya semua itu perlu perhatian khusus dari petugas di LPKA dalam memberikan pembinaan bagi narapidana anak.

Setelah adanya putusan oleh hakim yang menyatakan bahwa kepada Anak yang Berhadapan dengan Hukum $(\mathrm{ABH})$ diberikan pidana, dan harus menjalani pembinaan di LPKA Muara Bulian, narapidana anak tersebut harus menjalani tahap demi tahap dari program-program pembinaan yang ada di dalam LPKA sampai masa pidananya selesai dan keluar dari LPKA atau bila mana narapidana anak berkelakuan baik setelah narapidana anak memasuki tahap akhir yaitu 2/3 dari masa pidana atau sekurang-kurangnya 9 (Sembilan) bulan bagi anak pidana atau 6 (enam) bulan bagi anak Negara maka bagi anak tersebut dapat diajukan pembebasan bersyarat di mana status dari narapidana anak yang mendapatkan pembebasan bersyarat bukan lagi narapidana anak tapi berubah menjadi klien Pemasyarakatan di mana pembimbingan terhadap klien Pemasyarakatan dilakukan oleh Balai Pemasyarakatan (BAPAS). Oleh karena itu jelas bahwa sejak narapidana anak diberikan putusan pidana oleh hakim, narapidana anak tersebut harus menjalani pembinaan lebih banyak di dalam LPKA dibanding di luar LPKA, karena memang sedang menjalani masa hukumannya di LPKA. Perlu perhatian bagi para narapidana anak ini, ketika mereka memulai proses pembinaan, perlu dibimbing dengan baik, karena tidak mudah mereka melakukan adaptasi dengan lingkungan baru di LPKA. Jika penyesuaian narapidana bisa dilakukan maka proses pembinaan ini bisa berjalan dengan sesuai program yang sudah di susun di LPKA. Jika mereka belum mampu beradapatasi dan masih menolak dengan keadaan yang terjadi pada diri mereka, apalagi mereka harus berpisah dan berada jauh dari orang tua dan lingkungan 
semula mereka, maka sulit untuk mereka menerima apapun tahapan proses pembinaan yang diberikan kepada mereka. Kalo hal itu terjadi, maka hasil pembinaan yang di berikan tidak akan optimal.

Pembinaan narapidana anak adalah sebuah sistem di mana pembinaan narapidana sekarang adalah sistem pemasyarakatan. Narapidana anak bukan hanya dipandang sebagai objek tetapi juga sebagai subjek yang tidak berbeda dari manusia lain yang sewaktu-waktu dapat melakukan kesalahan atau kekhilafan yang dapat dikenakan pidana, ini dasar pemikiran ketika anak itu melakukan kesalahan dan melakukan perbuatan yang melanggar peraturan perundangundangan yang berlaku sampai mereka di jatuhi pidana dan harus menjalani pidana di LPKA, maka mereka harus di berikan pembinaan yang tepat, sehingga ketika selesai menjalankan hukum mereka mendapatkan bekal yang cukup untuk kembali beradapatasi di tengah masyarakat.Perlu bentuk-bentuk pembinaan yang tepat untuk mereka, yang disesuaikan dengan peraturan perundang-undangan yang mengatur tentang pembinaan narapidana ini, termasuk pembinaan narapidana anak.

LPKA Muara Bulian adalah merupakan tempat melaksanakan pembinaan terhadap narapidana anak yang berada dalam wilayah hukum yang terpisah dari orang dewasa mengingat bahwa pembinaan terhadap narapidana anak haruslah dibedakan dengan pembinaan terhadap orang dewasa sesuai amanat UndangUndang SPPA. Di LPKA Muara Bulian, narapidana anak diberikan pembinaan yang sesuai dengan pertumbuhan dan perkembangan narapidana anak itu sendiri baik yang menyangkut fisik, mental maupun sosial anak, sehingga para anrapidana ini tidak mengalami kesulitan ketika mengikuti program pembinaan selama mereka menjalani masa hukuman dari awal sampai selesai menjalani hukumannya.

Pelaksanaan pembinaan narapidana anak di LPKA Muara Bulian dilakukan berdasarkan pada Keputusan Menteri Kehakiman RI Nomor M.02-PK.04.10 Tahun 1990 Tentang Pola Pembinaan Narapidana/ Tahanan. Adapun hal tersebut dimulai dengan tahapan sebagai berikut:

1. "Penerimaan

a. Penerimaan anak didik yang baru masuk di LPKA wajib disertai surat-surat yang sah;

b. Penerimaan anak didik yang pertama kali dilakukan oleh petugas pintu gerbang yang ditunjuk oleh komandan jaga;

c. Setelah petugas yang ditunjuk menerima anak didik, segera diteliti dan pemeriksaan ulang terhadap surat-surat, barang-barang untuk dicocokkan dengan anak didik yang bersangkutan;

d. Setelah pencocokan selesai dilakukan penggeledahan terhadap anak didik yang baru diterima;

e. Dalam melakukan penggeledahan wajib mengindahkan norma-norma kesopanan;

f. Jika dalam penggeledahan ditemukan barang-barang terlarang, maka barang tersebut diamankan dan diselesaikan sesuai dengan ketentuan yang berlaku;

g. Setelah selesai penggeledahan anak didik diantar kepada petugas pendaftaran". 
2. "Pendaftaran

a. Petugas pendaftaran meneliti kembali sah atau tidaknya surat keputusan/surat penetapan/surat perintah dan pencocokan narapidana yang bersangkutan;

b. Mencatat identitas anak didik dalam buku daftar registrasi B;

c. Barang-barang perhiasan (berharga) yang mahal harganya dicatat dalam buku register $\mathrm{D}$ dan barang-barang berharga tersebut atau uang disimpan (dititipkan dalam lemari besi (brandkost));

d. Diambil teraan jari anak didik pada surat keputusan dan sepuluh jari, kanan kiri pada kartu daktiloskopi sesuai dengan ketentuan yang berlaku;

e. Mengambil foto anak didik;

f. Memeriksa anak didik pada dokter/para medis lembaga pemasyarakatan anak;

g. Membuat berita acara anak didik yang ditanda tangani bersama oleh petugas pendaftaran atas nama Kalapas anak dan pengawalnya kemudian mempersilahkan pengawal tersebut meninggalkan Lapas anak;

h. Kepada tahanan baru kemudian diberikan perlengkapan lapas".

3. "Penempatan

a. Tahananan baru ditempatkan di blok pengenalan lingkungan dan wajib mengikuti kegiatan pengenalan lingkungan;

b. Tahanan yang berpenyakit menular harus dikarantina dan dibuatkan catatan tentang penyakitnya, demikian juga terhadap tahanan yang berpenyakit lain dicatat dalam buku khusus untuk keperluan tersebut;

c. Setiap tahanan perlu diwawancarai untuk kepentingan perawatannya;

d. Dalam penempatan tahanan wajib memperhatikan penggolongan mereka, berdasarkan:

1) Jenis kelamin;

2) Umur;

3) Tingkat pemeriksaan;

4) Jenis perkara;

5) Kewarganegaraan".

Berdasarkan Keputusan Menteri Kehakiman RI Nomor M.02 PK.04.10 Tahun 1990 Tentang Pola Pembinaan Narapidana/Tahanan, maka beberapa bentuk Pembinaan terhadap anak warga binaan LPKA Muara Bulian yang diberikan adalah sebagai berikut:

1. Pembinaan Kepribadian

Dalam pembinaan kepribadian narapidana anak, LKPA menerapkan beberapa cara dengan tujuan supaya nantinya ketika anak sudah kembali ke orang tua mereka masing-masing dan masyarakat, bisa dilihat bahwa sudah terjadi perubahan kepribadian dari yang sebelumnya kurang baik menjadi pribadi yang lebih baik dan patuh terhadap hukum dan tidak mengulangi kesalahan yang sama, sehingga mereka harus berurus dengan hukum dan dijatuhi pidana. Dengan 
sudah diberikan pembinaan selama mereka menjalani masa hukuman di LPKA, mereka akhirnya menyadari kesalahan mereka dan berubah menjadi anak yang lebih baik untuk meneruskan kehidupan mereka kembali di tengah masyarakat. Adapun upaya yang dilakukan LPKA Muara Bulian yaitu:

a. Pembinaan Kesadaran Beragama

Usaha ini diperlukan agar dapat diteguhkan imannya terutama memberi pengertian agar para anak binaan di pemasyarakatan dapat menyadari akibat-akibat dari perbuatan yang benar dan perbuatan yang salah. Pembinaan kesadaran beragama dilakukan melalui kewajiban yang diberlakukan bagi semua narapidana anak untuk mengikuti sholat jamaah wajib 5 waktu.

b. Pembinaan Jasmani

Selain pembinaan rohani, lembaga juga memenuhi kebutuhan jasmani narapidana anak untuk menjaga kondisi kesehatan jasmani melalui olahraga, kesenian, dan kegiatan rekreasional sesuai dengan fasilitas yang tersedia di LPKA Muara Bulian.

c. Pembinaan Kemampuan Intelektual

Selain pembinaan agama, hal lain yang penting untuk diberikan kepada anak meskipun status anak tersebut adalah narapidana adalah pembinaan intelektual.

d. Pembinaan Kesadaran Hukum

Pembinaan kesadaran hukum warga binaan LPKA, dilaksanakan dengan memberikan penyuluhan hukum yang bertujuan agar tercapainya kesadaran hukum yang tinggi sehingga keadilan dapat ditegakkan, perlindungan terhadap harkat dan martabat manusia, dan ketertiban hukum. Penyuluhan hukum bertujuan untuk membentuk pribadi yang sadar hukum pada saat pembinaan selama di LPKA maupun saat kembali di tengah-tengah masyarakat.

2. Pembinaan Keterampilan

Selain pembinaan kepribadian, kepada tahanan LPKA Muara Bulian juga diberikan pembinaan ketrampilan. Pembinaan keterampilan tersebut diberikan melalui:

a. "Bimbingan keterampilan untuk mendukung usaha-usaha mandiri misalnya kerajinan tangan, industri rumah tangga dan sebagainya;

b. Bimbingan keterampilan untuk mendukung usaha-usaha industri kecil, misalnya pengelolaan bahan mentah dari sektor pertanian dan bahan alam menjadi bahan setengah jadi, misalnya mengolah rotan menjadi perabotan rumah tangga;

c. Keterampilan yang dikembangkan sesuai bakatnya masing- masing. Dalam hal ini mereka yang memiliki bakat tertentu diusahakan perkembangan bakatnya itu. Misalnya memiliki kemampuan merajut, maka diusahakan penyediaan peralatan rajut seperti benang, jarum, yang kemudia digunakan oleh tahanan untuk mengembangkan bakatnya itu". 
3. Pembinaan di Luar LPKA (Program Asimilasi)

Bagi narapidana anak yang memenuhi ketentuan diberikan kesempatan untuk mengikuti program asimilasi, hak asimilasi mereka dapat dicabut kembali. Kegiatan asimilasi yang ada di LPKA Muara Bulian antara lain seperti cuti mengunjungi keluarga, mengikuti kegiatan-kegiatan yang dilaksanakan seperti olah raga bersama masyarakat sekitar yang tetap mendapat bimbingan petugas LPKA Muara Bulian.

4. Pembinaan Rekreasi

Pembinaan ini meliputi pemberian hiburan dan informasi aktual bagi narapidana anak, seperti menonton televisi. Petugas menyediakan satu buah ruangan dan satu buat televisi sebagai sarana hiburan dan informasi bagi narapidana anak yang menjalani pembinaan di LPKA Muara Bulian. Diharapkan dengan adanya sarana hiburan tersebut narapidana anak tetap dapat mengikuti berita-berita aktual dan dapat terhibur dengan acara-acara dari televisi tersebut.

Bagi narapidana anak jangka pendek tidak dapat mengikuti kegiatan pendidikan paket $\mathrm{A}, \mathrm{B}$, dan $\mathrm{C}$ dikarenakan singkatnya masa pidana, sedangkan program kejar paket $\mathrm{A}, \mathrm{B}$, dan $\mathrm{C}$ tersebut merupakan pendidikan yang berkelanjutan dan membutuhkan waktu yang cukup panjang. Maka, pembinaan yang diterapkan terhadap narapidana jangka pendek berupa pembinaan harian sebagai mana yang telah penulis paparkan sebelumnya.

Untuk mengetahui setiap bakat yang dimiliki oleh anak, dilakukan penelitian tentang bakat dan minat apa yang dimiliki oleh mereka yang baru masuk LPKA. Pelaksanaan keterampilan bakat dilakukan melalui penyaluran dan pengembangan atas kecakapan alami yang dimiliki tahanan misalnya melukis, mengukir, merajut, dan lain lain. Keterampilan yang didukung lembaga merupakan keterampilan yang bermanfaat dan dapat dikembangkan lebih lanjut seperti mendaur ulang sampah plastik menjadi hiasan ruangan.

Pembinaan keterampilan penting untuk diberikan kepada para tahanan agar mereka dapat melakukan kegiatan yang bermanfaat di dalam lembaga. Karena, setelah keluar dari LPKA atau dikatakan bebas, tidak banyak sekolah formal yang kembali menerima mantan narapidana anak. Sehingga, jika tidak dibekali dengan keterampilan yang bermanfaat, maka mantan narapidana anak akan menjadi pengangguran yang tidak bisa melakukan apapun. Dengan keterampilan yang diperoleh selama masa tahanan, setidaknya anak bisa mengembangkan bakatnya tersebut di rumah atau lingkungannya tempat ia kembali nanti. Hasil karyanya pun bisa dijual dan menghasilkan uang atau dimanfaatkan sendiri di rumahnya. LPKA Muara Bulian mengharapkan warga binaannya berperilaku produktif selama di dalam tahanan supaya tidak hanya terpuruk dengan apa yang mereka alami atau hukuman yang harus mereka jalani. Pembinaan ini bisa berhasil jika narapidana anak memiliki tekad yang 
kuat untuk merubah dirinya menjadi anak yang lebih baik lagi dan tidak ingin mengulangi kesalahan yang sama yang membuat mereka harus di ganjar hukuman di LPKA. Jika mereka serius mengikuti pembinaan selama masa hukuman itu, maka ketika mereka kembali ke orang tua dan masyarakat mereka akan bisa menunjukan perubahan yang baik dari sikap kepribadian maupun keterampilan yang sudah mereka dapat dari hasil pembinaan di LPKA tersebut.

2. Kendala Yang Dihadapi Dalam Pembinaan Narapidana Anak Jangka Pendek Di LPKA Muara Bulian

1. Kurangnya perhatian dari keluarga narapidana.

Sebagian besar narapidana anak yang melakukan tindak pidana yang menjalani pembinaan di LPKA Muara Bulian adalah anak-anak yang orang tuanya sibuk dengan pekerjaan mereka masing-masing.

2. Kurangnya petugas dan tenaga ahli

Kurangnya jumlah petugas dan tenaga ahli dalam bidang keterampilan seperti perbengkelan, elektronik, montir dan sebagainya yang ada di LPKA Muara Bulian menjadi kendala dalam pembinaan yang dilakukan di LPKA tersebut, karena petugas yang ada di sana harus merangkap beberapa tugas/jabatan.

3. Kurangnya dana

Salah satu penunjang dari pelaksanaan pembinaan narapidana anak di LPKA Muara Bulian adalah dana.

4. Terbatasnya Sarana dan Prasarana

Sarana yang tersedia di LPKA Muara Bulian belum sepenuhnya tersedia, akibatnya banyak sarana yang seharusnya tersedia di LPKA Muara Bulian dan dapat dipergunakan dalam pembinaan narapidana anak tetapi tidak tersedia di sana. Sarana dan prasarana yang dirasakan kurang oleh narapidana anak misalnya dalam bidang olah raga dan keterampilan di mana dalam bidang olah raga sarana yang lengkap hanya ada untuk olah raga sepak bola dan bola voly, padahal mereka juga ingin agar sarana bagi olah raga lainnya seperti bulu tangkis, tenis meja, dan lainnya dapat terpenuhi. Begitu juga dalam bidang keterampilan kurangnya alat-alat penunjang pertukangan dan alat elektronika.

5. Kurangnya partisipasi masyarakat

Partisipasi masyarakat dalam proses pembinaan narapidana anak sangat kurang, hal ini dapat kita lihat dari kurangnya perhatian dan sikap masa bodoh terhadap narapidana anak yang menjalani pembinaan di LPKA Muara Bulian.

\section{SIMPULAN}

Artikel ini menyimpulkan, bahwa pemenuhan hak narapidana anak di dalam Lembaga Pembinaan Khusus Anak Muara Bulian sudah sesuai dengan UndangUndang Nomor 11 Tahun 2012 tentang Sistem Peradilan Pidana Anak, akan tetapi masih perlu ditingkatkan dan ditambah lagi Sumber Daya Manusia yang khusus untuk membina anak di Lembaga Pembinaan tersebut. Selanjutnya kendala dalam pelaksanaan pembinaan narapidana anak yang dijatuhi pidana penjara jangka pendek di LKPA Muara Bulian adalah kurangnya perhatian dari keluarga 
narapidana anak, kurangnya petugas dan tenaga ahli, kurangnya dana, terbatasnya sarana dan prasarana, kurangnya partisipasi masyarakat.

\section{DAFTAR PUSTAKA}

\section{Dokumen Hukum}

Republik Indonesia, Undang-Undang Nomor 12 Tahun 1995 Tentang Pemasyarakatan. LNRI Tahun 1995 Nomor 77. TLNRI Nomor 3080.

Undang-Undang Nomor 11 Tahun 2012 Tentang Sistem Peradilan Pidana Anak. LNRI 2011 Nomor 104. TLNRI Nomor 5332.

Undang-Undang Nomor 35 tahun 2014 tentang Perubahan Atas Undang-Undang Nomor 23 tahun 2002 tentang Perlindungan Anak. LNRI 2012 Tahun 2012. TNLRI Nomor 5332.

ـ Peraturan Pemerintah Nomor 31 Tahun 1999 tentang Pembinaan dan Pembimbingan pada Warga Binaan Pemasyarakatan. LNRI 68 Tahun 1999. TLNRI Nomor 3842.

Peraturan Pemerintah Nomor 32 Tahun 1999 tentang Syarat dan Tata Cara Pelaksanaan Hak Warga Binaan Pemasyarakatan. LNRI 69 Tahun 1999. TLNRI Nomor 3846.

Peraturan Menteri Negara Pemberdayaan Perempuan dan Perlindungan Anak Nomor 15 Tahun 2010 tentang Pedoman Umum Penanganan Anak yang Berhadapan dengan Hukum.

Keputusan Menteri Kehakiman Republik Indonesia Nomor M.02-PK.04.10 Tahun 1990 tentang Pola Pembinaan Narapidana/Tahanan.

\section{Buku}

Abdullah, Syukur, Kumpulan Makalah Study Implementasi Latar Belakang Konsep Pendekatan dan Relevansinya dalam Pembangunan, Ujung Pandang: Penerbit Buku Persadi, 1987.

Arief, Barda Nawawi. Kapita selekla Hukum Pidana, Bandung: Penerbit Buku Citra Aditya Bakti, 2010.

Departemen Pendidikan Nasional, Kamus Besar Bahasa Indonesia, Balai Pustaka.

Harsono. Sistem Baru Pembinaan Narapidana, Solo: Penerbit Buku Djambatap, 1995. 
Mertokusumo, Sudikno. Peradilan Anak di Indonesia, Bandung: Penerbit Buku Mandar maju, 1997.

Nasution, Bahder Johan. Metode Penelitian Hukum, Bandung: Penerbit Buku Mandar Maju, 2008.

Pramudya, Yan. PUSPA, Kamus Hukum, Semarang: Penerbit Buku Aneka Ilmu.

Prinst, Drwan. Hukum Anak Indonesia, Jakarta: Penerbit Buku Citra Aditya Bakti, 1997.

Rahayu, Sri. Hukum Penitensier Indonesia, Intisari Kuliah, Fakultas Hukum Universitas Jambi.

Schaffrneister, D. De Kofte Vriiheidsstrcf als Wijetiidsstnf, Bandung: Penerbit Buku Citra Aditya Bakti, 2010.

Setiady, Tolib. Pokok-pokok Hukum Penitensier Indonesia, Bandung: Penerbit Buku Alfabeta, 2009.

Simanjuntak, B. dan I. L Pasaribu. Membina dan Mengembangkan Generasi Muda, Bandung: Penerbit Buku Tarsito, 1990.

Simon, A. Josis dan Thomas Sunaryo. Studi Kebudayaan Lembaga Pemasyarakatan di Indonesia. Bandung: Penerbit Buku Lubuk Agung, 2010.

Jurnal:

Hafrida et.al. "Pembinaan Narapidana Anak Di Lembaga Pemasyarakatan Anak Sei. Buluh Muara Bulian" (Kajian Terhadap Proses Penyelesaian Perkara Pidana Anak Tanpa Pidana Penjara (Diversi) Menurut Uu No. 11 Tahun 2012 Tentang Sistem Peradilan Pidana Anak). Vol. 5, No. 3, Jurnal Ilmu Hukum, (2015). https://doi.org/10.26858/publikan.v5i3.1613.

Hafrida, "Restorative Justice in Juvenile Justice to Formulate Integrated Child Criminal Court", Jurnal Hukum dan Peradilan, Vol. 8, No. 3, (2019). http://dx.doi.org/10.25216/ihp.8.3.2019.439-457

Nurhaliza, Rina, dkk. "Pelaksanaan Kesepakatan Diversi Pada Tingkat Penyidikan dalam Sistem Peradilan Anak”, PAMPAS Journal, Vol. 1 No. 1, (2020). https://doi.org/10.22437/pampas.v1i1.8097

Rahayu, Sri dan Yulia Monita, "Pemenuhan Hak-Hak Anak Sebagai Pelaku Tindak Pidana Dalam Perspektif Undang-Undang Pengadilan Anak Dan Implementasinya Di Pengadilan Negeri Jambi”, Jurnal Ilmu Hukum, (2015). https://www.neliti.com/id/publications/43306/pemenuhan-hak-hak-anaksebagai-pelaku-tindak-pidana-dalam-perspektif-undang-unda.

Rahayu, Sri. "Diversi Sebagai Alternatif Penyelesaian Perkara Tindak Pidana Yang Dilakukan Anak Dalam Perspektif Sistem Peradilan Pidana Anak", Jurnal Ilmu Hukum, (2015). https://www.neliti.com/id/publications/43317/diversisebagai-alternatif-penyelesaian-perkara-tindak-pidana-yang-dilakukan-ana 
Wahyudi, Dheny. "Perlindungan Terhadap Anak Yang Berhadapan Dengan Hukum Melalui Pendekatan Restorative Justice", Jurnal Ilmu Hukum, (2015). https://www.neliti.com/id/publications/43318/perlindungan-terhadap-anakyang-berhadapan-dengan-hukum-melalui-pendekatan-resto

Widayanti, Lidya Suryani. "Pidana Kerja Sosial Sebagai Alternatif Pidana Penjara Jangka Pendek", Vol. 17, No. 4, (2012). https://doi.org/10.22212/kajian.v17i4.376

Yudaningsih, Lilik Purwastuti. "Penanganan Perkara Anak Melalui Restorative Justice”, Jurnal Ilmu Hukum, (2014). https://media.neliti.com/media/publications/43277-ID-penanganan-perkaraanak-melalui-restorative-justice.pdf

\section{Internet}

https://www.hukumonline.com//klinik/detail/ulasan/it56bd54ec1d07/pendididikan -bagi-anak-di-lembaga-pembinaan-khusus-anak-lkpa/

http://www.artikata.com/arti-360090-pembinaan. 